\title{
Reactivity of 5a,6-Anhydrotetracycline Platinum(II) Complex with Biological Nucleophiles: a Theoretical Study
}

\author{
Bruna L. Marcial, ${ }^{a}$ Luiz Antônio S. Costa, ${ }^{b}$ Wagner B. De Almeida ${ }^{c}$ and Hélio F. Dos Santos $*, a$ \\ ${ }^{a}$ Núcleo de Estudos em Química Computacional, Departamento de Química, Universidade Federal de Juiz de Fora, \\ 36036-330 Juiz de Fora-MG, Brazil
}

${ }^{b}$ Escola Preparatória de Cadetes do Ar, Departamento de Ensino da Aeronáutica, Comando da Aeronáutica, Rua Santos Dumont, 149, 36205-970 Barbacena-MG, Brazil

${ }^{c}$ Laboratório de Química Computacional e Modelagem Molecular, Departamento de Química, Universidade Federal de Minas Gerais, 31270-901 Belo Horizonte-MG, Brazil

\begin{abstract}
No presente artigo, métodos teóricos foram utilizados para o estudo da interação entre o complexo 5a,6-anidrotetraciclina-dicloro-platina(II) (AHTC-Pt) e os nucleófilos adenina (A), guanina $(\mathrm{G})$, cisteína (Cys) e metionina (Met). A espécie $\left[\mathrm{Pt}(\mathrm{AHTC}) \mathrm{Cl}\left(\mathrm{H}_{2} \mathrm{O}\right)\right]^{+}$foi considerada como reagente em todos os processos investigados. Os valores calculados para $\Delta \mathrm{G}_{\mathrm{a} \text { aq }}$ no nível B3LYP/6-311+G(2d,p) foram 21,7 e 20,7 kcal mol ${ }^{-1}$ para as interações com A e G, respectivamente, os quais estão em acordo com o comportamento esperado, sendo a reação com $\mathrm{G}$ mais rápida $\left(\Delta \mathrm{G}_{\mathrm{a}}^{\mathrm{expt}}=18,5 \mathrm{kcal} \mathrm{mol}^{-1}\right.$ para $\left.\mathrm{G}\right)$. Para os processos envolvendo os aminoácidos, as barreiras de energia calculadas foram 17,6 (Cys) e 18,5 kcal mol-1 (Met), as quais são ligeiramente menores do que os valores experimentais para a cisplatina $\left(20,5\right.$ e 20,2 $\mathrm{kcal} \mathrm{mol}^{-1}$, respectivamente). Esses resultados mostram que a reatividade do complexo AHTC-Pt é comparável a da cisplatina e, portanto, o mesmo pode ser considerado um sistema relevante para o desenvolvimento de novos agentes antitumorais.
\end{abstract}

This paper describes a theoretical analysis of the interaction between 5a,6-anhydrotetracycline platinum(II) complex (AHTC-Pt) and some biological nucleophiles; adenine (A), guanine (G), cysteine (Cys) and methionine (Met). The aquated species $\left[\mathrm{Pt}(\mathrm{AHTC}) \mathrm{Cl}\left(\mathrm{H}_{2} \mathrm{O}\right)\right]^{+}$was taken as reagent for the processes studied here. For DNA bases (A and $\mathrm{G})$, the calculated values for $\Delta \mathrm{G}$ at the B3LYP/6-311+G(2d,p) level were 21.7 and $20.7 \mathrm{kcal} \mathrm{mol}^{-1}$ for interaction with $\mathrm{A}$ and $\mathrm{G}$, respectively, which are in accordance with the expected behavior of faster process involving $\mathrm{G}$. These values are higher than the experimental activation energy for the parent compound cisplatin (18.5 kcal mol ${ }^{-1}$ for interaction with $\left.\mathrm{G}\right)$. For the process involving the amino-acids, the barriers were 17.6 (Cys) and $18.5 \mathrm{kcal} \mathrm{mol}^{-1}$ (Met), which are lower than the observed values for cisplatin (20.5 and $20.2 \mathrm{kcal} \mathrm{mol}^{-1}$, respectively). These outcomes show that AHTC-Pt hybrid complex may be considered a promising lead compound in the development of novel anticancer drugs based on platinum complex.

Keywords: cisplatin analogues, tetracyclines, ab initio calculations

\section{Introduction}

Tetracyclines (TCs) constitute a family of agents with antimicrobial activity, which comprises natural and semisynthetic analogues. ${ }^{1}$ These molecules are primarily used as antibiotic in animal diseases, however some chemically modified tetracyclines (CMTs) have also

\footnotetext{
*e-mail: helio.santos@ufjf.edu.br
}

been found to suppress the formation and magnitude of metastases associated with certain cancers. ${ }^{2}$ The active TCs have a general structure with the fused tetracycle, natural configuration of chiral centers and the presence of the essential dimethylamino group at position C4 (Scheme 1). The removal of this group eliminates the antimicrobial activity, as desired for some CMTs. ${ }^{1,2}$ The acquired bacterial resistance has been the main problem with these drugs, responsible to shift off most of the representatives 


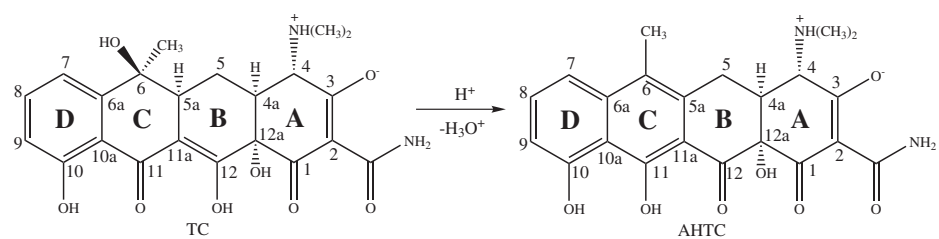

Scheme 1. Structures of tetracycline (TC) and its anhydrous derivative (AHTC). The numbering scheme used herein is indicated.

from human chemotherapy. The resistance mechanisms have been well understood with two main routes being established, which are the decreasing in the drug uptake and the activation of pumps that drive out drugs from cells. ${ }^{3-6}$ Besides these overall descriptions, some molecular features are described as coordination with divalent metal ions, mainly $\mathrm{Mg}(\mathrm{II}){ }^{3-6}$

The strong chelating ability of TCs has motivated the researchers to search for novel inorganic complexes that could be used to overcome resistance and side effects of the drugs. ${ }^{7-12} \mathrm{Mg}$ (II) and $\mathrm{Ca}$ (II) are the main ions coordinated to the free fraction of the drug,${ }^{7,10}$ nonetheless the transition metals complexes have also been of interest. ${ }^{8,9,11,12}$ The 5a,6-anhydrotetracycline platinum(II) complex (AHTCPt) was firstly synthesized by Aly et al.,${ }^{9}$ who assigned the coordination site on the ring A. Afterwards, Pereira-Maia and collaborators ${ }^{11}$ reported the $\mathrm{Pt}(\mathrm{II})$ complex with the parent compound TC and some of its analogues, named doxycline, oxytetracycline and chlortetracycline. ${ }^{12}$ The latter species were tested against sensitive and resistant $E$. Coli strains, proving to be more potent than the free antibiotic against resistant strains. ${ }^{12}$ All the complexes obtained so far have a general stoichiometry $\left[\mathrm{Pt}(\mathrm{TC}) \mathrm{Cl}_{2}\right]$ with Pt(II) bound to O3-Oam on ring A (Scheme 2). Despite the greater interest in antibiotic activity, the complex of TCs with Pt(II) may also be viewed as a cisplatin analogue, where the vector ligand (TCs) should remain coordinated to the Pt center throughout the whole process leading to interaction with the final target DNA. The presence of TCs ligand certainly will modify significantly the physicalchemistry properties of the drug and the DNA binding mode. ${ }^{13}$ For flat derivatives, such as the $\mathrm{BCD}$ ring system in AHTC (see Scheme 1), the intercalation may also play a role on DNA binding, therefore the AHTC-Pt might

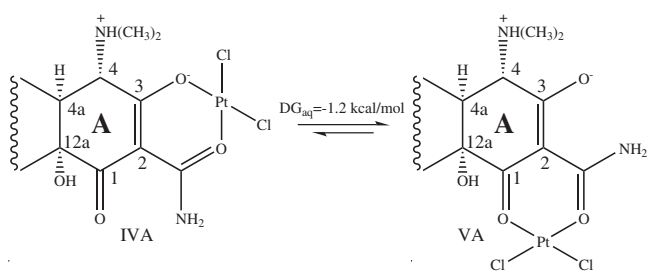

Scheme 2. Most favorable AHTC-Pt complexes proposed in our previous paper. The coordination site IVA is supported by experimental findings. be expected to act as a hybrid metalating-intercalating agent. $^{14,15}$

In the last few years our group has given a contribution to the tetracycline $e^{16-23}$ and cisplatin ${ }^{23-28}$ computational chemistry, investigating structures, spectroscopy and reactivity of free ligand and complexed forms. These studies have assisted the experimentalist to elucidate the coordination modes of TCs with some metal ions as $\mathrm{Mg}(\mathrm{II}), \mathrm{Zn}(\mathrm{II}), \mathrm{Al}(\mathrm{III})$ and $\mathrm{Pt}(\mathrm{II})$, as well as, quantifying thermodynamic and kinetic properties of important reactive processes. For the AHTC-Pt complex, our previous paper ${ }^{23}$ clarified on quantitative basis the coordination of the metal in the ring A. Among 14 distinct complexation modes, we proposed an equilibrium between structures IVA and VA (Scheme 2), slightly shifted toward VA $\left(\Delta \mathrm{G}_{\mathrm{aq}}=\right.$ $\left.-1.2 \mathrm{kcal} \mathrm{mol}^{-1}\right)$. The comparison between experimental and theoretical NMR data supported the presence of form IVA in larger amount in the medium. In addition to the structures and spectroscopic properties, we also analyzed the aquation reaction, showing that the AHTC-Pt compound reacts with water at similar rate as cisplatin does. In aqueous solution the second-order rate constant is (in $\mathrm{mol}^{-1} \mathrm{~L} \mathrm{~s}^{-1}$ ): $4.5 \times 10^{-6}$ for AHTC-Pt and 2.5-8.5 $\times 10^{-5}$ for cisplatin (experimental value from references 29-31). This is an important result, which puts the AHTC-Pt complex as a promising lead compound in developing new cisplatin analogues. Following this observations, the next step is to evaluate the reactivity of this complex with other important biological nucleophiles, representing proteins and nucleic acid. In the present work we explore, by means of theoretical calculations, the potential energy surface (PES) for the reaction of AHTCPt aquated species, $\left[\mathrm{Pt}(\mathrm{AHTC}) \mathrm{Cl}\left(\mathrm{H}_{2} \mathrm{O}\right)\right]^{+}$, with sulfurcontaining amino acids methionine (Met) and cysteine (Cys) and DNA bases guanine (G) and adenine (A). The reaction paths are completely described given structures and spectroscopic properties of reactive species in addition to the thermodynamic and kinetic quantities.

\section{Theoretical Details}

The reaction considered in the present work is represented in equation 1 , where "Nu" stands for the nucleophiles: Met, Cys, A and G. 


$$
\begin{aligned}
{\left[\mathrm{Pt}(\mathrm{AHTC}) \mathrm{Cl}\left(\mathrm{H}_{2} \mathrm{O}\right)\right]^{+}+\mathrm{Nu} \rightarrow } \\
{[\mathrm{Pt}(\mathrm{AHTC}) \mathrm{Cl}(\mathrm{Nu})]^{+}+\mathrm{H}_{2} \mathrm{O} }
\end{aligned}
$$

The AHTC ligand, in the aquated species [Pt(AHTC) $\left.\mathrm{Cl}\left(\mathrm{H}_{2} \mathrm{O}\right)\right]^{+}$, is on the neutral zwitterionic state $\left(\mathrm{LH}_{2}^{ \pm}\right)^{23}$ and the coordination mode was chosen as IVA (see Scheme 2). The amino acids structures with $\mathrm{COOH}$ and $\mathrm{NH}_{2}$ groups were used as described previously for cisplatin parent compound. ${ }^{28}$

The kinetic properties were calculated within the supermolecule approach, where reagents and products are treated as molecular complexes. These species (called hereafter intermediates I-1 and I-2 for reagent and product, respectively) are located on the PES for each exchange ligand process through intrinsic reaction coordinate (IRC) calculation, ${ }^{32}$ starting from transition state (TS) structures. This procedure ensures the true species participating in the reaction pathway. An associative mechanism is assumed for all processes analyzed, with the TS represented by a distorted bipyramidal-trigonal geometry.

The geometries of all reactive molecules, including reagents, products, intermediates and transition states, where fully optimized in gas phase at the Hartree-Fock (HF) and density functional theory (DFT), with the B3LYP functional, ${ }^{33,34}$ using standard split-valence basis sets with additional polarization functions on heavy atoms $(6-31 G(d))$. For platinum atom, the effective core potential of Hay and Wadt ${ }^{35}$ were used for core atomic orbitals and the corresponding double-zeta basis-set for valence shell (this is specified by the label LanL2DZ). The structures were further characterized either as minimum (no imaginary frequency) or first-order TS (only one imaginary frequency) on the PES by means of harmonic frequency analysis. The activation free energy in gas phase $\left(\Delta \mathrm{G}_{\mathrm{a}, \mathrm{g}}\right)$ was calculated by equation 2 , where $\Delta \mathrm{E}_{\mathrm{a}, \mathrm{g}}$ ele-nuc comes from the electronic plus nuclear contribution and $\Delta \mathrm{G}_{\mathrm{a}, \mathrm{g}}^{\mathrm{T}}$ from thermal correction at $25^{\circ} \mathrm{C}$ and $1 \mathrm{~atm}$.

$\Delta \mathrm{G}_{\mathrm{a}, \mathrm{g}}=\Delta \mathrm{E}_{\mathrm{a}, \mathrm{g}}^{\text {ele-nuc }}+\Delta \mathrm{G}_{\mathrm{a}, \mathrm{g}}^{\mathrm{T}}$

In order to investigate the role played by the basis-set on the energy profile, single point calculation was also performed with enhanced basis-set $(6-311+\mathrm{G}(2 \mathrm{~d}, \mathrm{p}))$. At this level of theory the free energy values are calculated through equation 2 , but using the corresponding values of the electronic plus nuclear contribution obtained at the B3LYP/6-311+G(2d,p)//B3LYP/6-31G(d) level (double slash means single point calculation). The thermodynamic and kinetic quantities were also calculated in water solution $\left(\varepsilon_{\mathrm{r}}=78.39\right)$ using the polarizable continuum model $(\mathrm{PCM})$ within the integral equation formalism (IEF) ${ }^{36}$ The gas phase optimized geometries were considered for energy calculation in solution, with the solute cavity constructed according to the UAHF scheme ${ }^{36}$ including the electrostatic and non-electrostatic contributions to the solvation energy. The activation free energy in solution is given by equation 3 , where the last term on the right hand is the difference in solvation energies for TS and intermediate adducts calculated at the same level as the geometry.

$\Delta \mathrm{G}_{\mathrm{a}, \mathrm{aq}}=\Delta \mathrm{G}_{\mathrm{a}, \mathrm{g}}+\delta \Delta \mathrm{G}_{\mathrm{a}}^{\mathrm{solv}}$

The calculations were carried out using Gaussian 03 revision D. $01^{37}$ with the convergence criteria set as the default of the program. ${ }^{37}$

\section{Results and Discussion}

The structure of $\left[\mathrm{Pt}(\mathrm{AHTC}) \mathrm{Cl}_{2}\right]$ complex and its hydrolysis process, leading to $\left[\mathrm{Pt}(\mathrm{AHTC}) \mathrm{Cl}\left(\mathrm{H}_{2} \mathrm{O}\right)\right]^{+}$aquated species, were previously discussed. ${ }^{23}$ The main outcome from that work was the unambiguous characterization of the coordination mode through ${ }^{1} \mathrm{H}$ and ${ }^{13} \mathrm{C}$ NMR analyses. Two almost degenerated forms were proposed as represented in Scheme 2, with IVA fitting better the experimental data. This form was used in the present work to describe the reaction 1. In this first part of the paper the structures and NMR spectra for the products, $[\mathrm{Pt}(\mathrm{AHTC}) \mathrm{Cl}(\mathrm{Nu})]^{+}(\mathrm{Nu}=$ G, A, Cys, Met), are discussed based only on theoretical results, once experimental information is not available for such molecules. We hope that the following results may assist the experimentalist in future studies, identifying adducts found in tetracyclines and biomolecules mixtures, even though very simple molecular models are used here as nucleophiles.

Table 1 collects the structural parameters around metal center, where the numbering sequence given in Scheme 1 was used. Firstly analyzing the coordination shell, it can be noted that the metal geometry is close to square-planar for all complexes, with $\angle \mathrm{X}(\mathrm{Nu})-\mathrm{Pt}-\mathrm{Cl}$ and $\angle \mathrm{X}(\mathrm{Nu})-\mathrm{Pt}-\mathrm{O} 3$ bond angles in the range of $87-94^{\circ}$ and the torsion $\delta \mathrm{X}-\mathrm{O} 3-$ Oam-Cl found equal to $180-187^{\circ}$. The slightly greater outof-plane distortion found for $\mathrm{G}\left(7^{\circ}\right)$ is due the two weak electrostatic interactions involving the carbonyl at position C6 of $\mathrm{G}$ with the methyl groups from dimethylamonium moiety in AHTC (see Figure 1). The shortest distances between these groups were calculated to be 2.47 and $2.13 \AA$. For $\mathrm{A}$ this interaction is also observed with the distance between methyl groups and $\mathrm{NH}_{2}$ at position $\mathrm{C} 6$ found to be $2.69 \AA$ (see Figure 1). We do not expect a significant effect of these interactions on the stability of complexes, but these should affect on a measurable amount the NMR spectra, as 
will be discussed latter. The main changes in the structure of the products are on the rPt-X bond lengths, which are close to $2.0 \AA$ for $\mathrm{A}$ and $\mathrm{G}$ complexes and close to $2.3 \AA$ for Cys and Met compounds. The ring A of AHTC, which is directly involved in the coordination with metal ion, also shows similar geometries for the distinct complexes, with a canonical structure for the tricarbonyl system defined by longer C3-O3 and Cam-Oam bonds ( $c a .1 .28 \AA$ ) compared to $\mathrm{C} 1-\mathrm{O} 1(1.24 \AA)$ and shorter $\mathrm{C} 3-\mathrm{C} 2$ bond $(1.41 \AA)$ than C2-C1 (1.45 $\AA$ ), regardless the type of nucleophile.

The NMR spectra were calculated at the B3LYP/6$311+\mathrm{G}(2 \mathrm{~d}, \mathrm{p}) / / \mathrm{B} 3 \mathrm{LYP} / 6-31 \mathrm{G}(\mathrm{d})$ level by using the GaugeIndependent Atomic Orbital (GIAO) method $^{38}$ that provides ${ }^{1} \mathrm{H}$ and ${ }^{13} \mathrm{C}$ magnetic shielding constants $(\sigma)$. The chemical shifts for selected atoms were obtained on the $\delta$-scale relative to TMS through equation 4 ,

$\delta_{\mathrm{i}}=\sigma^{\mathrm{TMS}}-\sigma_{\mathrm{i}}$

where the values of $\sigma^{\mathrm{TMS}}=182.4656$ for $\mathrm{C}$ and $\sigma^{\mathrm{TMS}}=$ 31.8821 for $\mathrm{H}$ were obtained at B3LYP/6-311+G(2d,p) level of theory. The relative chemical shifts for the main atoms on the ring A of ligand are represented in Figure 2.
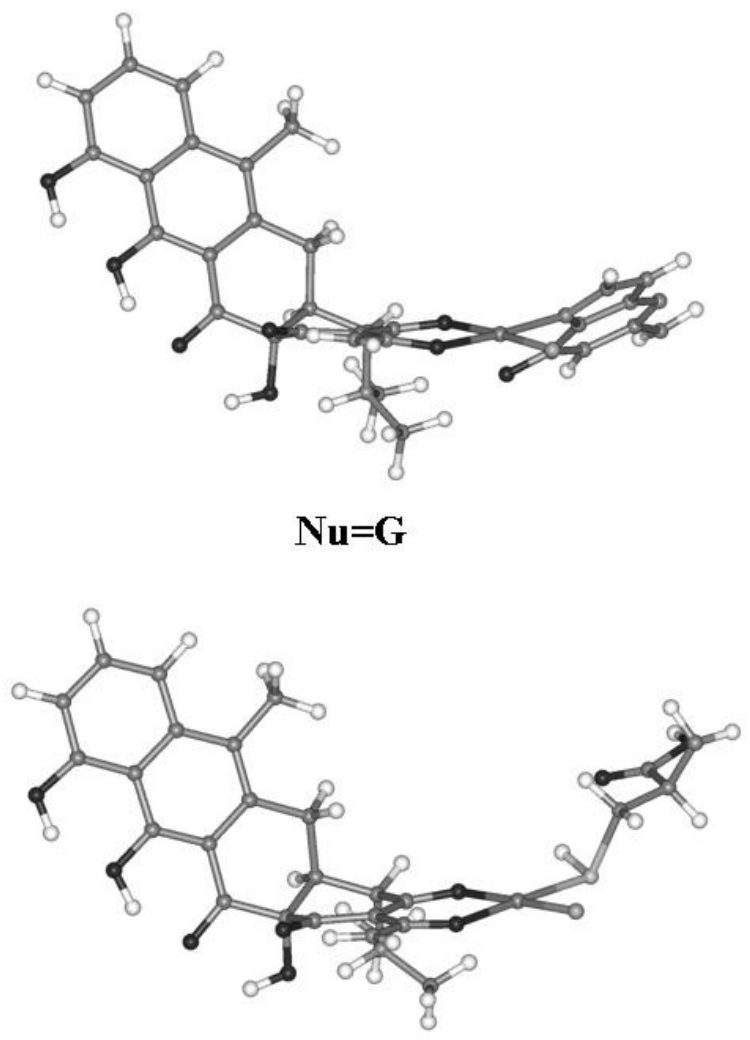

$\mathbf{N u}=\mathbf{C y s}$
Table 1. Structural parameters calculated at the B3LYP/6-31G(d)/ LanL2DZ level of theory for the distinct complexes [Pt(AHTC)Cl(Nu) $]^{+}$. The bond lengths (r) are in $\AA$ and bond $(\angle)$ and torsion $(\delta)$ angles in degrees. The numbering sequence used is given in Scheme 1

\begin{tabular}{lcccc}
\hline & \multicolumn{4}{c}{$\mathrm{Nu}$} \\
\cline { 2 - 5 } & $\mathrm{Cys}$ & $\mathrm{Met}$ & $\mathrm{A}$ & $\mathrm{G}$ \\
\hline $\mathrm{rPt}-\mathrm{X}(\mathrm{Nu})$ & 2.32 & 2.33 & 2.02 & 2.05 \\
$\mathrm{rPt}-\mathrm{Cl}$ & 2.34 & 2.34 & 2.33 & 2.34 \\
rPt-O3 & 2.06 & 2.07 & 2.07 & 2.05 \\
rPt-Oam & 2.04 & 2.05 & 2.03 & 2.03 \\
rC3-O3 & 1.28 & 1.28 & 1.28 & 1.27 \\
rC2-C3 & 1.41 & 1.41 & 1.41 & 1.41 \\
rC2-Cam & 1.49 & 1.48 & 1.48 & 1.48 \\
rCam-Oam & 1.27 & 1.27 & 1.27 & 1.27 \\
rC2-C1 & 1.47 & 1.47 & 1.47 & 1.47 \\
rC1-O1 & 1.23 & 1.23 & 1.23 & 1.23 \\
$\angle \mathrm{X}(\mathrm{Nu})-\mathrm{Pt}-\mathrm{Cl}$ & 87.9 & 88.7 & 88.6 & 89.3 \\
$\angle \mathrm{X}(\mathrm{Nu})-\mathrm{Pt}-\mathrm{O} 3$ & 92.8 & 94.0 & 91.9 & 93.5 \\
$\angle \mathrm{Cl}-\mathrm{Pt}-\mathrm{Oam}$ & 89.9 & 88.8 & 90.5 & 88.3 \\
$\angle \mathrm{O} 3-\mathrm{Pt}-\mathrm{Oam}$ & 89.2 & 88.3 & 88.8 & 88.9 \\
$\delta \mathrm{X}-\mathrm{O} 3-\mathrm{O}-\mathrm{Oam}-\mathrm{Cl}$ & 180 & 180 & 181 & 187 \\
\hline & & & &
\end{tabular}
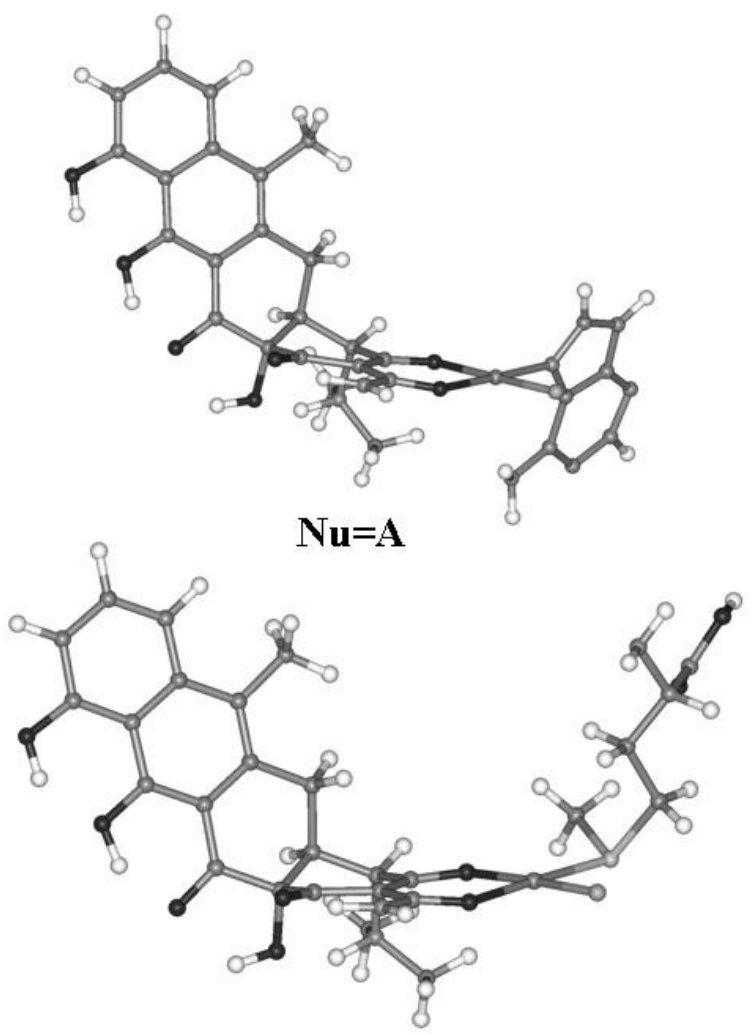

Nu=Met

Figure 1. B3LYP/6-31G(d)/LanL2DZ optimized geometries for the complexes [Pt(AHTC)Cl(Nu) $]^{+}$with $\mathrm{Nu}=\mathrm{G}, \mathrm{A}$, Cys and Met, indicated in the figure. Some structural parameters are given in Table 1. 
The absolute values calculated for the free ligand (not shown) were used as reference. It should be pointed out that the chemical shifts for free AHTC calculated at B3LYP/6$311+\mathrm{G}(2 \mathrm{~d}, \mathrm{p})$ level are slightly different from those given in reference 23 calculated at B3LYP/6-311+G(d,p). Looking at Figure 2 we see that the NMR spectra are not very sensitive to the type of nucleophile, showing the same general profile for all complexes. From Figure 2a it can be seen that most of the carbon atoms in the ring A display down field shift relative to the free ligand, with larger values calculated for $\mathrm{C} 3$ and Camd, which belong to the groups directly bound to the metal. For these atoms the average absolute chemical shifts, taking the four complexes studied, were 184 (C3) and $175 \mathrm{ppm}$ (Camd), being the values for $\mathrm{G}$ and $\mathrm{A}$ complexes slightly higher (185 and 176, respectively). For the free AHTC, the respective calculated chemical shifts are 176.4 (C3) and 169.2 (Camd), which agree within 5\% with the experimental data ${ }^{39}$ This nice agreement suggests that in the absence of experimental data, the calculated absolute and relative (Figure 2a) chemical shifts may be used as guide in the characterization of the complexes. Nonetheless, bearing in mind the precision of 5\%, we can not precisely assign the ${ }^{13} \mathrm{C}$ NMR to distinguish between complexes with different nucleophiles analyzed.

The ${ }^{1} \mathrm{H}$ NMR chemical shifts depicted in Figure $2 b$ also show important features that might be used to identify the

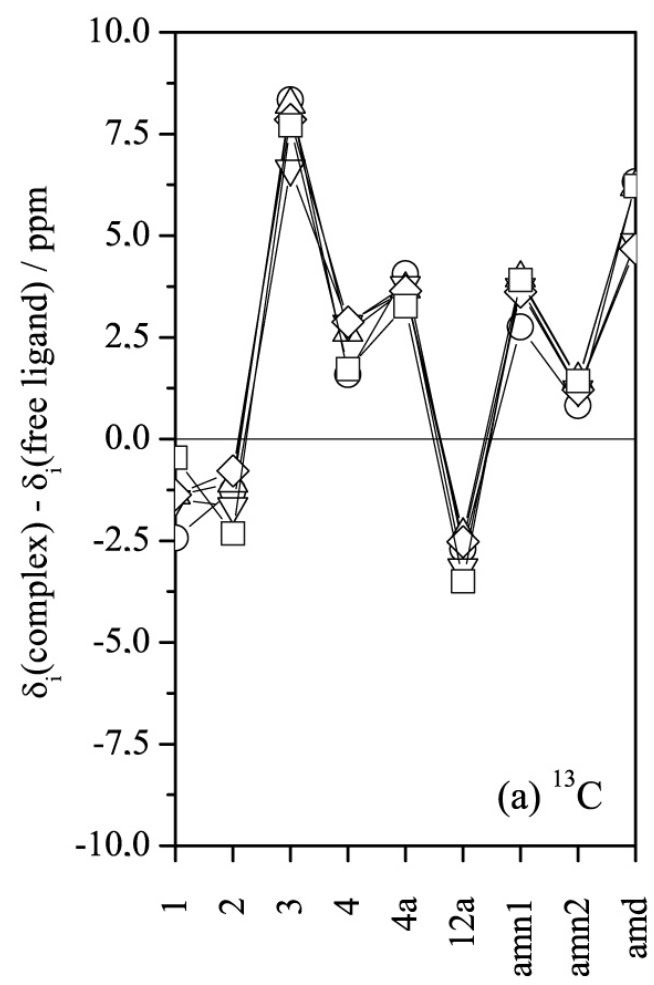

structures of the complexes. The hydrogen atoms in the dimethylamonium (DMA) moiety are affected in different ways depending on the type of nucleophile. Taking the average chemical shift for each methyl group, we found $\delta$ equal to $2.8 \mathrm{ppm}$ for both $-\mathrm{CH}_{3}$ in the free ligand. This outcome is in perfect accordance with the experimental finding ${ }^{11}$ that showed only one peak at $2.9 \mathrm{ppm}$. The theoretical data for the coordinate Pt(II) complexes with Cys and Met also give only one average value at $2.8 \mathrm{ppm}$, therefore showing a similar ${ }^{1} \mathrm{H}$ NMR spectrum to the ligand in what the DMA group is concerned. For $\mathrm{G}$ and $\mathrm{A}$, a splitting of these signals are predicted from $2.8 \mathrm{ppm}$ to 3.2 and $3.8 \mathrm{ppm}(\mathrm{G})$ and to 2.8 and $3.3 \mathrm{ppm}(\mathrm{A})$, with the lower field peak assigned to the methyl interacting with nucleophiles (see Figure 1). For G both $-\mathrm{CH}_{3}$ groups are close to the carbonyl at $\mathrm{C} 6$, thus a low field shift is found for both methyls, whereas for A only one methyl interacts with the $\mathrm{NH}_{2}$ at $\mathrm{C} 6$ (see Figures 1 and 2). It is opportune to refer to our previous paper ${ }^{23}$ where we showed that even for the $\left[\mathrm{Pt}(\mathrm{AHTC}) \mathrm{Cl}_{2}\right]$ complex, coordinated in the mode IVA, a low field shift was obtained for the DMA methyl groups. This is not only consequence of the AHTC-Pt interaction, but mainly due to a conformational change in the ligand from twisted to extended (see reference 17) upon the complex formation, putting the $-\mathrm{CH}_{3}$ and $\mathrm{Cl}$ groups closer. This same extended form was considered for all

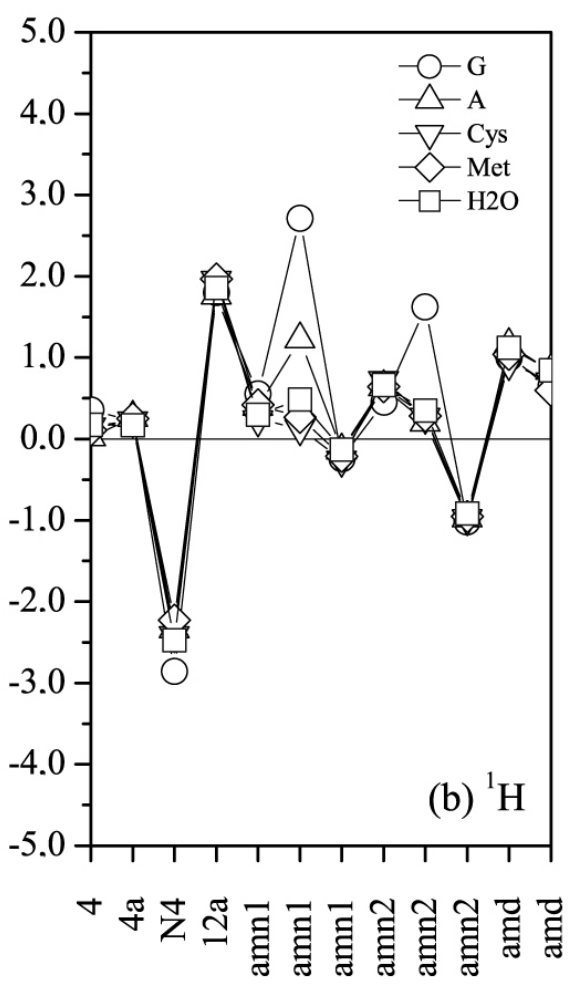

Figure 2. ${ }^{13} \mathrm{C}$ (a) and ${ }^{1} \mathrm{H}$ (b) relative chemical shifts for the complexes $[\mathrm{Pt}(\mathrm{AHTC}) \mathrm{Cl}(\mathrm{Nu})]^{+}$with $\mathrm{Nu}=\mathrm{G}, \mathrm{A}, \mathrm{Cys}$ and Met, indicated in the figure. The values for the free AHTC ligand were taken as reference. The absolute chemical shifts were calculated by means of equation 4 . 
compounds analyzed here. At the level of theory used in the present work (B3LYP/6-311+G(2d,p)), the signals of DMA in the [Pt(AHTC) $\left.\mathrm{Cl}_{2}\right]$ complex split to 2.5 and 3.5 $\mathrm{ppm}$, which is a very similar pattern to the spectrum found for A complex. Therefore, we can conclude that this region of the ${ }^{1} \mathrm{H}$ NMR spectrum can be taken as an important probe in the characterization of the complexes.

Before discussing the whole reaction path, it is opportune to shortly analyze the thermodynamics of equation (1) for the distinct nucleophiles. The gas phase data shows the $\mathrm{G}$ reaction as the most favorable in gas phase with $\Delta \mathrm{G}_{\mathrm{R}, \text { gas }}=-22.9 \mathrm{kcal} \mathrm{mol}^{-1}$, followed by Met $\left(-9.6 \mathrm{kcal} \mathrm{mol}^{-1}\right), \mathrm{A}\left(-8.9 \mathrm{kcal} \mathrm{mol}^{-1}\right)$ and Cys $\left(-1.1 \mathrm{kcal} \mathrm{mol}^{-1}\right)$. The inclusion of solvent changes the trends, showing the Cys complexation as the most favorable process $\left(\Delta \mathrm{G}_{\mathrm{R}, \mathrm{aq}}=-13.8 \mathrm{kcal} \mathrm{mol}^{-1}\right)$. For the other reactions the predicted free energy in aqueous solution at the B3LYP/6$31 \mathrm{G}(\mathrm{d}) / \mathrm{LanL} 2 \mathrm{DZ}$ level were $-9.9(\mathrm{G}),-0.6$ (A) and $1.6 \mathrm{kcal}$ $\mathrm{mol}^{-1}$ (Met). The results in aqueous solution are in qualitative agreement with the expected behavior of more favorable processes for $\mathrm{G}$ than $\mathrm{A}$ and for Cys than Met.

The coordination of platinum to DNA bases is the key step towards the biological action of platinum-based drugs. This link bends the helix axis to a substantial amount, inducing programmed cell death (apoptosis). ${ }^{40}$ Despite the geometric aspects of complex, which directly interfere in the DNA binding, the kinetic factors play a primary role on the reaction pathway, considering the competition with several thermodynamically favorable side processes occurring simultaneously in the biological medium. Therefore, the understanding at a molecular level of these processes is essential to rationalize new molecules with desired biochemical properties.

Among the large number of theoretical studies published in the last ten years on the interaction of cisplatin like molecules with DNA and sulfur-containing molecules, the most important of them are referenced in the recent papers of
Burda and co-workers ${ }^{41,42}$ and Dos Santos and co-workers. ${ }^{27,28}$ These articles deal with standard mode of action of cisplatin, where the first step towards the formation of bifunctional adducts with DNA and proteins is the binding of monoaqua species with nucleophiles, as represented in equation 1 . This process is investigated herein for the AHTC-Pt complex focusing in kinetic properties, considering the purine bases ( $\mathrm{G}$ and $\mathrm{A}$ ) and the free amino acids (Cys and Met) as the simplest biological models. An associative mechanism is assumed for all reactions, passing through a pentacoordinated transition state. For $\mathrm{G}$ and $\mathrm{A}$, the reactions involve the displacement of the aqua ligand of the chloroaqua complex by the N7 site of G or A. In the case of the amino acids, the entering ligand coordinates through the sulfur atom. The B3LYP/6-31G(d)/LanL2DZ optimized geometries for TSG and TSA-1, participating in the water/purine-base exchange pathway, are depicted in Figure 3, with some calculated structural parameters quoted in Table 2.

Looking at Figure 3, we see that the structures proposed are the most hydrogen-bonded assisted, with the substituent at position $\mathrm{C} 6$ of the nucleophiles interacting with water leaving ligand through a hydrogen bond. In TSG, water acts as proton donor with $\mathrm{dHw} . . \mathrm{O} 6=1.82 \AA$. This pattern is different in TSA-1, where water is the proton acceptor group $\left(\mathrm{dNH}_{2} \ldots \mathrm{Ow}=1.99 \AA\right)$. This difference in the interaction mode between the leaving and the entering ligands promotes a distortion in the geometry of the coordination shell. The rPt-N7 and rPt-Ow bond lengths were 2.53 and $2.43 \AA$ for $\mathrm{G}$ and 2.60 and $2.51 \AA$ for A, respectively. The bond angle $\angle \mathrm{Ow}$-Pt-N7 was larger for $\mathrm{G}\left(73.3^{\circ}\right)$ than for A $\left(64.0^{\circ}\right)$, reflecting directly on the degree of trigonality $(\tau)$, which is a structural index computed as in equation 5, where $\beta$ is the angle formed by the axial ligands and $\alpha$ the largest angle on the equatorial plane.

$$
\tau=(\beta-\alpha) / 60^{\circ}
$$

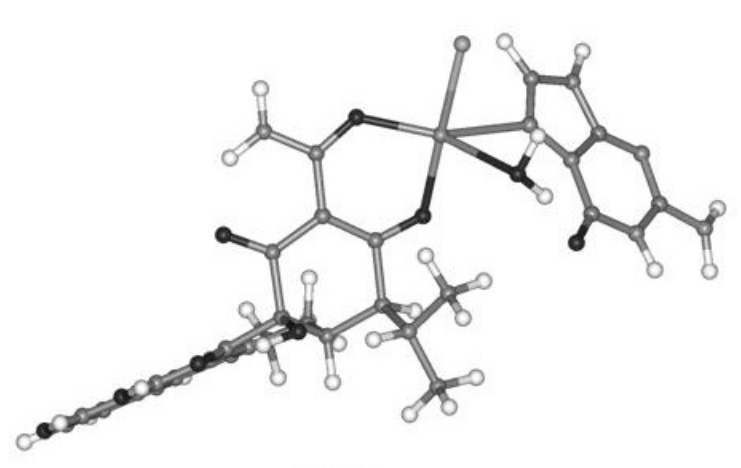

TSG

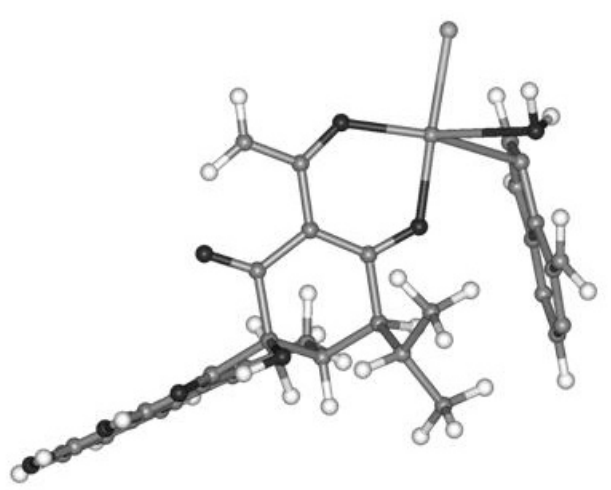

TSA-1

Figure 3. B3LYP/6-31G(d)/LanL2DZ optimized structures for the transition states (TS) involved in the binding of AHTC-Pt aquated species with purine bases $\mathrm{G}$ and $\mathrm{A}$. Some structural parameters are given in Table 2. 
Table 2. Structural parameters calculated at the B3LYP/6-31G(d)/LanL2DZ level of theory for the intermediates (I-1 and I-2) and transition states (TS) involved in the reaction path for formation of $[\mathrm{Pt}(\mathrm{AHTC}) \mathrm{Cl}(\mathrm{Nu})]^{+}$, where $\mathrm{Nu}$ stands for $\mathrm{G}$ and $\mathrm{A}$. The bond lengths (r) are in $\AA$ and bond $(\angle)$ and torsion $(\delta)$ angles in degrees. The numbering sequence used is given in Scheme 1

\begin{tabular}{|c|c|c|c|c|c|c|}
\hline & \multicolumn{3}{|c|}{$\mathrm{G}$} & \multicolumn{3}{|c|}{$\mathrm{A}$} \\
\hline & $\mathrm{I}-1$ & TSG & $\mathrm{I}-2$ & $\mathrm{I}-1$ & TSA-1 & $\mathrm{I}-2$ \\
\hline rPt-N7 & 4.22 & 2.53 & 2.03 & 3.88 & 2.60 & 2.02 \\
\hline rPt-Ow & 2.07 & 2.43 & 3.34 & 2.09 & 2.51 & 3.33 \\
\hline rPt-Oam & 2.00 & 2.03 & 2.03 & 2.00 & 2.00 & 2.03 \\
\hline rPt-O3 & 2.05 & 2.05 & 2.07 & 2.05 & 2.04 & 2.05 \\
\hline $\mathrm{rPt}-\mathrm{Cl}$ & 2.33 & 2.34 & 2.34 & 2.33 & 2.34 & 2.34 \\
\hline $\mathrm{dHw} \ldots \mathrm{O}^{\mathrm{a}}$ & 1.69 & 1.82 & 1.99 & - & - & - \\
\hline $\mathrm{dNH} 2 \ldots \mathrm{Ow}^{\mathrm{a}}$ & - & - & - & 2.16 & 1.99 & 1.88 \\
\hline $\mathrm{dHw} \ldots \mathrm{N7}^{\mathrm{a}}$ & 1.82 & - & - & 1.63 & - & - \\
\hline$\angle \mathrm{Ow}-\mathrm{Pt}-\mathrm{N} 7$ & 33.3 & 73.3 & 11.0 & 39.4 & 64.0 & 92.2 \\
\hline$\delta:[\mathrm{N} 7-\mathrm{Pt}-\mathrm{Oam}-\mathrm{Ow}]$ & - & -177.6 & - & - & -174.9 & - \\
\hline$\tau^{\mathrm{b}}$ & - & 0.54 & - & - & 0.46 & - \\
\hline
\end{tabular}

${ }^{\mathrm{a}}$ Intermolecular distances in $\AA$. ${ }^{\mathrm{b}}$ See equation 5 .

For $\tau=1$ the metal center geometry can be viewed as a perfect $D_{3 \mathrm{~h}}$ trigonal bipyramidal $\left(\alpha=120^{\circ}\right.$ and $\left.\beta=180^{\circ}\right)$ and for $\tau=0$ the geometry is assigned as $\mathrm{C}_{4 \mathrm{v}}$ square pyramidal $\left(\alpha=\beta=90^{\circ}\right){ }^{43}$ For the reaction with purine bases, $\tau$ were $0.54(\mathrm{G})$ and $0.46(\mathrm{~A})$, indicating an almost half and half mixture of square-pyramidal and trigonal bipyramidal geometries for both transition states. These values are close to those found for the TS in the cisplatin reaction with $\tau=0.53 .{ }^{27}$ The spatial orientations of nucleophiles are also affected due to the intramolecular hydrogen bond. The angle between the equatorial plane of metal center, defined by $\delta$ in Table 2, and the plane of purine bases was equal to $58^{\circ}$ for $\mathrm{G}$ and $95^{\circ}$ for $\mathrm{A}$, putting A perpendicular to the reaction center (see Figure 3 ). The structures shown in Figure 3 can be compared to those described in references 27 and 44. For the reaction of cisplatin aquated species with $\mathrm{G}^{27}$ the TS geometry was stabilized by a hydrogen bond between the axial $\mathrm{NH}_{3}$ and the carbonyl at $\mathrm{C} 6$. The rPt-N7 and rPt-Ow, calculated at the same level of theory used in the present paper, were 2.53 and $2.42 \AA,{ }^{27}$ in close agreement with the values found here (see Table 2 ). This was also the case for $\angle \mathrm{Ow}-\mathrm{Pt}-\mathrm{N} 7$, found equal to $73.1^{\circ}$ in reference 27 . These geometrical similarities are expected, since the leaving and the entering ligands are the same. The more pronounced difference is on the spatial arrangement of $\mathrm{G}$ around metal center, which is primarily determined by interaction with side chains in the AHTC vector ligand. The
TS for A binding to cisplatin diaqua species was described in reference 44 where two pathways were proposed with the preferred one passing through a TS showing a hydrogen bond between the $\mathrm{NH}_{2}$ moiety of $\mathrm{A}$ and the axial water. The level of theory used for geometry optimization was the same as considered here, however, the authors observed intramolecular proton transfer from water to $\mathrm{NH}_{2}$ upon geometry optimization, which was likely attributed to the +2 charge of diaquated cisplatin and the lack of solvent in the calculations. Despite this non-physical phenomenon, the calculated activation energy was in good accordance to the experiment. ${ }^{44}$ The energy profiles for the whole reactions studies in the present paper will be described latter.

It is interesting to notice that the TS for purine-bases described in the literature ${ }^{27,44}$ showed intramolecular interactions with axial ligand. For the TS involving the AHTC-Pt complex and $\mathrm{G}$ and A, these are not favorable due to the nature of AHTC ligand (see Figure 3). The TSG shown in Figure 3 may be considered unique, however for TSA two possible structures may be thought having the water ligand acting either as proton acceptor (TSA-1 in Figure 3 ) or as proton donor (not shown). The optimized geometry for the latter (named TSA-2) is similar to TSA-1 concerning the coordination shell, with rPt-N7 and rPt-Ow found to be 2.57 and $2.44 \AA$, respectively. The angle between the entering and the leaving ligands increases to $74.4^{\circ}$, changing $\tau$ to 0.49 . The hydrogen bond $\mathrm{dHw} \ldots \mathrm{NH}_{2}$ was slightly 
shorter $(1.90 \AA)$, but its energy is higher by $2.7 \mathrm{kcal} \mathrm{mol}^{-1}$ at the B3LYP/6-31G(d)/LanL2DZ level of theory in gas phase. The choice of the best reaction pathway is not based only on the stability of TS, but depends also on the energies of reagents, which within the supermolecule approach are different for distinct reaction coordinates. This point will be discussed latter when energy is considered.

The optimized geometries for the TS involving the Cys and Met binding are depicted in Figure 4 and the main parameters collected in Table 3. Among the large number of possible structures of TS for such flexible amino acid ligands, only two were considered for each process in the present paper, differing by the conformation around the $\mathrm{Pt}(\mathrm{II})$ center. As mentioned in the last paragraph, only those geometries leading to the lowest energy barrier are used for tracking the reaction pathway, thus the data reported in Table 3 refers to only the preferred TS geometries, named TSC- 1 and TSM- 1 . The analysis of the values in Table 3 shows that the reaction center parameters are similar for TSC-1 and TSM-1, being rPt-S and rPt-Ow around 2.9 and $2.5 \AA$, respectively. The angle defined between the entering and the leaving groups are smaller for Met TS $\left(72.8^{\circ}\right)$ than Cys TS $\left(74.1^{\circ}\right)$, decreasing $\tau$ to 0.41 in the former, which characterizes the TSM-1 structure as $60 \%$ square pyramidal. Interesting is to compare the data in Table 3 to the corresponding values reported recently for interaction of Cys and Met with the parent complex cisplatin. ${ }^{28}$ In the reaction analyzed in reference 28 the leaving group is the chloride instead of water as the processes investigated in the present study. For cisplatin reaction, both the TS structures showed rPt-S close to $2.7 \AA$ and $\angle \mathrm{Cl}-\mathrm{Pt}-\mathrm{S}$ bond angle around $85^{\circ}$. As an outcome from these differences, $\tau$ was calculated to be 0.70 , assigning the TS geometries as $70 \%$ trigonal bipyramidal. This analysis reveals an interesting feature of the reaction pathways, suggesting two distinct associative mechanisms for cisplatin and its AHTC-Pt analogue in what $\mathrm{Cl} / \mathrm{H}_{2} \mathrm{O}$ and sulfur-containing amino acid exchange processes are concerned.

The two other TS found for Cys and Met reaction named TSC-2 and TSM-2, respectively, were close in energy to the respective isomers TSC- 1 and TSM-1, with gas phase $\Delta \mathrm{E}$ found to be 0.5 and $3.1 \mathrm{kcal} \mathrm{mol}^{-1}$ favoring TSM-2 and TSC-2, respectively. The main torsion in TSM-2 occurs around Pt-S bond, with the amino acid side chain over the hydrophobic tetracycline ring system. As a consequence the rPt-S bond was $0.1 \AA$ longer than found in TSM-1 (see Table 3 ) and the $\angle \mathrm{Ow}-\mathrm{Pt}-\mathrm{S}=65.9^{\circ}$, increasing $\tau$ to 0.46 . In the case of TSC- 2 a strong hydrogen bond was observed between water and carboxyl group of the amino acid moiety ( $\mathrm{dHw} . . \mathrm{O}=1.84 \AA$ ), which is the main factor stabilizing TSC-2 relative to TSC-1.

All the TS geometries obtained in the present study were characterized as first-order TS through harmonic frequency calculation. The imaginary frequencies obtained at the B3LYP/6-31G(d)/LanL2DZ level were 150.8i (TSG), 190.6i (TSA-1), 159.2i (TSC-1) and 155.0i cm-1 (TSM-1), with the normal mode undoubtedly assigned as asymmetric Pt-N7/S plus Pt-Ow stretching on the equatorial plane of the metal center. The activation energies and rate constants were calculated using the supermolecule approach, with reagents (I-1) and products (I-2) treated as molecular complexes. The initial geometries for these supermolecules were found from a long IRC calculation including around 120 points for each process analyzed. The last point in each direction of IRC was further fully optimized to ensure the complete convergence to minimum point. It is worth mentioning that the IRC must be long enough to guarantee the convergence for the correct intermediates. This is more

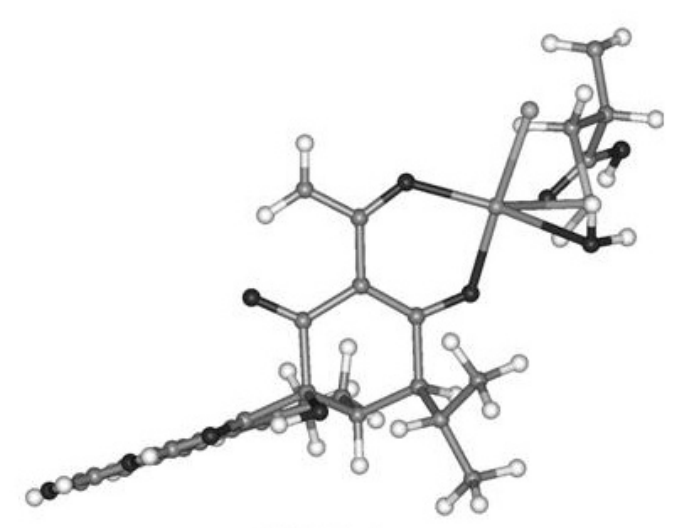

TSC-1

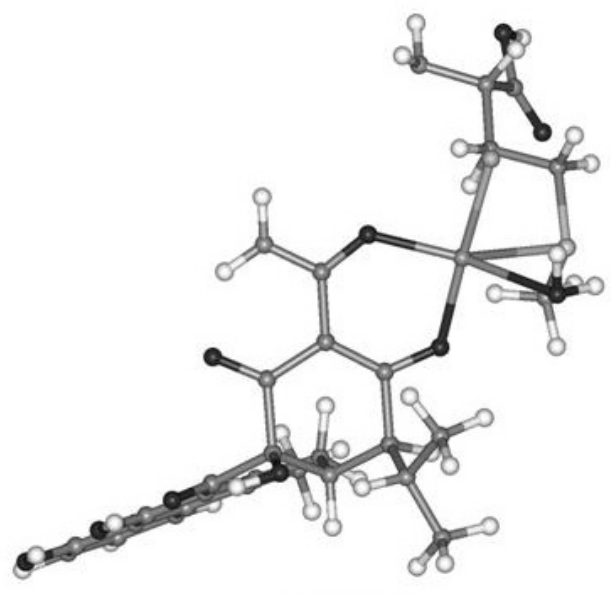

TSM-1

Figure 4. B3LYP/6-31G(d)/LanL2DZ optimized structures for the transition states (TS) involved in the binding of AHTC-Pt aquated species with sulfurcontaining amino acids Cys and Met. Some structural parameters are given in Table 3. 
Table 3. Structural parameters calculated at the B3LYP/6-31G(d)/LanL2DZ level of theory for the intermediates (I-1 and I-2) and transition states (TS) involved in the reaction path for formation of $[\mathrm{Pt}(\mathrm{AHTC}) \mathrm{Cl}(\mathrm{Nu})]^{+}$, where $\mathrm{Nu}$ stands for Cys and Met. The bond lengths $(\mathrm{r})$ are in $\AA$ and bond $(\angle)$ and torsion $(\delta)$ angles in degrees. The numbering sequence used is given in Scheme 1

\begin{tabular}{|c|c|c|c|c|c|c|}
\hline & \multicolumn{3}{|c|}{ Cys } & \multicolumn{3}{|c|}{ Met } \\
\hline & $\mathrm{I}-1$ & TSC-1 & $\mathrm{I}-2$ & $\mathrm{I}-1$ & TSM-1 & $\mathrm{I}-2$ \\
\hline rPt-S & 4.24 & 2.85 & 2.32 & 4.46 & 2.88 & 2.32 \\
\hline rPt-Ow & 2.09 & 2.47 & 3.43 & 2.09 & 2.44 & 3.39 \\
\hline rPt-Oam & 1.99 & 2.03 & 2.05 & 2.00 & 2.04 & 2.06 \\
\hline rPt-O3 & 2.05 & 2.04 & 2.06 & 2.04 & 2.04 & 2.07 \\
\hline $\mathrm{rPt}-\mathrm{Cl}$ & 2.33 & 2.34 & 2.34 & 2.34 & 2.34 & 2.34 \\
\hline $\mathrm{dHw} \ldots \mathrm{S}^{\mathrm{a}}$ & 2.17 & - & - & 2.16 & - & - \\
\hline$\angle \mathrm{Ow}-\mathrm{Pt}-\mathrm{S}$ & 46.0 & 74.1 & 119.0 & 40.3 & 72.8 & 118.0 \\
\hline$\delta:[\mathrm{S}-\mathrm{Pt}-\mathrm{Oam}-\mathrm{Ow}]$ & - & -172.8 & - & - & -171.3 & - \\
\hline$\tau^{\mathrm{b}}$ & - & 0.46 & - & - & 0.41 & - \\
\hline
\end{tabular}

antermolecular distances in $\AA$. ${ }^{\mathrm{b} S e e}$ equation 5.

relevant for nucleophiles like those studied here, which lead to weakly bound complexes, possessing flat PES with multiple minima profile. The predicted bond lengths and angles for the intermediates I- 1 and I-2 for all processes are included in Tables 2 and 3. From an overall analysis of the results it can be clearly seen the variation of $\mathrm{rPt}-\mathrm{N} 7 / \mathrm{S}$ and rPt-Ow along the I-1 $\rightarrow$ TS $\rightarrow$ I-2 pathway, showing the $\mathrm{Pt}-\mathrm{N} 7 / \mathrm{S}$ bond formation and Pt-Ow bond breakage on the equatorial plane. Independent of the species analyzed the difference in bond lengths for purine-bases and amino acids complexes are mainly on the rPt-N7 and rPt-S, with the latter longer than the former. Some intermolecular distances are also shown for intermediate complexes, describing the attractive short contacts between the interacting species. The I-1 adducts formed with purine bases are stabilized by strong hydrogen bonds involving the coordinated water and the N7 and C6 moieties of DNA bases. For I-1 in the $\mathrm{G}$ process, two strong hydrogen bonds were computed with $\mathrm{dHw} . . \mathrm{N} 7$ and $\mathrm{dHw}$...O6 found equal to 1.82 and $1.69 \AA$, respectively. For A reaction only one relevant hydrogen bond was observed with dHw...N7 = $1.63 \AA$. The intermediate I-1 participating in the reaction with Cys and Met did not show any strong intermolecular interaction, with the shortest contact found for Hw...S, whose distance was about $2.2 \AA$ in both cases. In the I- 2 species, the uncoordinated water molecule interacts with complex in different ways. For $\mathrm{G}$, the water is hydrogen bonded to O6, with $\mathrm{dHw} . . \mathrm{O} 6=1.99 \AA$ and for A adduct the water molecule acts as proton acceptor for $\mathrm{NH}_{2}$ at $\mathrm{C} 6$ and proton donor for $\mathrm{Cl}$. The distances characterize both hydrogen bond as short, being $\mathrm{dNH}_{2} \ldots \mathrm{Ow}=1.88 \AA$ and $\mathrm{dHw} \ldots \mathrm{Cl}=2.39 \AA .{ }^{45}$ For the amino acids a weak hydrogen bond is observed between water and Oam moiety of AHTC ligand, with $\mathrm{dHw} . . . \mathrm{Oam} \sim 2.1$ A. The optimized geometries for the intermediates are not shown here, but are supplied as Supplementary Information.

Previous discussion defines completely the structural features for all species involved in the reactions pathways, which determines the energy profiles analyzed hereafter. For A, Cys and Met that showed two distinct transition states, we calculated energy barriers for both processes in gas phase at the HF/6-31G(d)/LanL2DZ level of theory. This procedure was the same used previously ${ }^{28}$ to decide about the preferred reaction path for Cys and Met binding processes, with the choice being that giving the lowest energy barrier. The $\Delta \mathrm{G}_{\mathrm{a}, \mathrm{g}}$ ele-nuc values at the $\mathrm{HF}$ level were (in kcal mol ${ }^{-1}$ ): 18.4 (TSA-1), 23.5 (TSA-2), 18.8 (TSC-1), 41.6 (TSC-2), 18.6 (TSM-1) and 21.6 (TSM-2), showing the TS-1 structures as those leading to the lowest energy barriers (see Figures 3 and 4). The greater difference found for Cys processes is a consequence of the stability of I-1 found from TSC-2 path, what is quite stable due to short hydrogen bonds. Based in our experiences with analogue systems, ${ }^{27,28}$ we do not expect any change in this trend at the DFT level, therefore the conclusion drawn from HF calculations may be taken as reliable with significantly lower computational cost compared to the B3LYP level. The geometric features for these structures and their 
Table 4. Activation energies ( $\left.\mathrm{kcal} \mathrm{mol}^{-1}\right)$ and rate constant $\left(\mathrm{mol}^{-1} \mathrm{~L} \mathrm{~s}^{-1}\right)$ calculated for AHTC-Pt aquated species binding processes to purine bases $\mathrm{G}$ and $\mathrm{A}$ and sulfur-containing amino acids Cys and Met. The $\mathrm{k}_{2}$ values shown were calculated in aqueous solution

\begin{tabular}{|c|c|c|c|c|c|c|}
\hline & $\Delta \mathrm{G}_{\mathrm{a}, \mathrm{g}}^{\text {ele-nuc }}$ & $\Delta \mathrm{G}_{\mathrm{a}, \mathrm{g}}^{\mathrm{T}}$ & $\delta \Delta \mathrm{G}_{\mathrm{a}}^{\text {solv }}$ & $\Delta \mathrm{G}_{\mathrm{a}}^{\mathrm{a}}$ & $\Delta \mathrm{G}_{\mathrm{a}, \mathrm{aq}} \mathrm{b}$ & $10^{2} \mathrm{k}_{2}{ }^{\mathrm{c}}$ \\
\hline \multicolumn{7}{|l|}{ G } \\
\hline B3LYP/6-31G(d)/LanL2DZ & 21.9 & -1.70 & 1.19 & 20.2 & 21.4 & 0.14 \\
\hline B3LYP/6-311+G(2d,p)/LanL2DZ & 21.2 & - & - & 19.5 & 20.7 & 0.44 \\
\hline \multicolumn{7}{|l|}{ A } \\
\hline B3LYP/6-31G(d)/LanL2DZ & 21.0 & -0.18 & 2.23 & 20.9 & 23.1 & 0.01 \\
\hline B3LYP/6-311+G(2d,p)/LanL2DZ & 19.6 & - & - & 19.4 & 21.7 & 0.08 \\
\hline \multicolumn{7}{|l|}{ Met } \\
\hline B3LYP/6-31G(d)/LanL2DZ & 18.6 & -0.39 & 1.25 & 18.2 & 19.4 & 3.55 \\
\hline B3LYP/6-311+G(2d,p)/LanL2DZ & 17.6 & - & - & 17.2 & 18.5 & 17.64 \\
\hline \multicolumn{7}{|l|}{ Cys } \\
\hline B3LYP/6-31G(d)/LanL2DZ & 19.4 & -0.10 & -0.47 & 19.3 & 18.8 & 9.77 \\
\hline B3LYP/6-311+G(2d,p)/LanL2DZ & 18.2 & - & - & 18.1 & 17.6 & 74.07 \\
\hline
\end{tabular}

${ }^{\mathrm{a}}$ Calculated by equation $2 .{ }^{\mathrm{b}} \mathrm{C}$ alculated by equation $3 .{ }^{\mathrm{c}}$ Calculated by equation $6 .{ }^{\mathrm{d}}$ The thermal correction $\left(\Delta \mathrm{G}_{\mathrm{a}, \mathrm{g}}^{\mathrm{T}}\right)$ and relative solvation energy $\left(\delta \Delta \mathrm{G}_{\mathrm{a}}^{\text {solv }}\right)$ were obtained at the B3LYP/6-31G(d)/Lanl2DZ level of theory.

corresponding intermediates (I-1 and I-2) were discussed above. Hereafter we focus on the energy properties of the four reactions analyzed, accounting for the interaction of $\left[\mathrm{Pt}(\mathrm{AHTC}) \mathrm{Cl}\left(\mathrm{H}_{2} \mathrm{O}\right)\right]^{+}$aquated species with purine bases $(\mathrm{G}$ and $\mathrm{A}$ ) and the amino acids (Cys and Met). Remembering that the reagents and products are treated as molecular complexes, the whole process can be represented by I- $1 \rightarrow$ $\mathrm{TS} \rightarrow \mathrm{I}-2$, where the barrier from I-1 $\rightarrow$ TS is of primary importance, assuming a competition between the several reactions.

All the contributions for free energy barrier in gas phase (equation 2) and in aqueous solution (equation 3) are given in Table 4 at the B3LYP DFT level using two distinct basis sets, 6-31G(d) and 6-311+G(2d,p). These levels of theory have been used in our previous papers for cisplatin analogues, ${ }^{23,28}$ given energy barriers within $1 \mathrm{kcal} \mathrm{mol}^{-1}$ on average from experimental data. Therefore, we are confident of the values reported here, without need to improve the level of calculation. Firstly analyzing the gas phase data we see that reactions with amino acids are faster than with purine bases. For Cys and Met binding the free energy barriers were 19.3 and $18.2 \mathrm{kcal} \mathrm{mol}^{-1}$, respectively, compared to 20.9 (A) and $20.2 \mathrm{kcal} \mathrm{mol}^{-1}$ (G) (B3LYP/6$31 \mathrm{G}(\mathrm{d}) / \mathrm{LanL} 2 \mathrm{DZ}$ values). These values are close to the electronic plus nuclear energy change $\left(\Delta \mathrm{E}_{\mathrm{a}, \mathrm{g}}^{\text {ele-nuc }}\right)$, with thermal correction contribution found to be less than $2 \%$ for A, Cys and Met. For G process, the $\Delta \mathrm{G}_{\mathrm{a}, \mathrm{g}}^{\mathrm{T}}$ quantity contributes with $7 \%$ decreasing the barrier, which is large enough to shift down the free energy barrier to a value lower than those obtained for A (see Table 4). The improvement of the level of theory to a triple-zeta quality basis-set
(B3LYP/6-311+G(2d,p)/LanL2DZ//B3LYP/6-31G(d)/ LanL2DZ) decreases the energy barriers for all processes by $1 \mathrm{kcal} \mathrm{mol}^{-1}$ on average, keeping the same qualitative trend. In aqueous solution the barriers are slightly higher (6-11\%) compared to gas phase, except for Cys interaction, which value was $18.8 \mathrm{kcal} \mathrm{mol}^{-1}\left(0.5 \mathrm{kcal} \mathrm{mol}^{-1}\right.$ lower than in gas phase) at the B3LYP/6-31G(d)/LanL2DZ level. For the other processes the calculated $\Delta \mathrm{G}_{\mathrm{a}, \mathrm{aq}}$ barriers were $21.4(\mathrm{G}), 23.1$ (A) and 19.4 (Met) at the B3LYP/6-31G(d)/ LanL2DZ level of theory. It is now interesting to refer to our previous papers on the kinetics of $\mathrm{G}^{27}$ and amino acids (Cys and Met $)^{28}$ binding to cisplatin. In reference 28 the thermal correction accounted for $c a$. $3 \%$ of free energy barrier in gas phase, in close agreement with the estimative reported here for Cys and Met interactions. Nonetheless, in aqueous solution the results were somewhat different, with solvent effect corresponding to an important contribution around $30 \%$ of the activation Gibbs free energy in reference 28. These are likely attributed to the type of vector ligand and to the chemical process investigated in reference 28 , where the chloride is the leaving group. Besides these theoretical features, the predicted trend for cisplatin ${ }^{28}$ was also different from our present work, with Met barrier found smaller by $1.3 \mathrm{kcal} \mathrm{mol}^{-1}$ than Cys one at the very same level of theory used here. Experimentally, the average values for cisplatin reaction from two experiments are 20.2 (Met) and $20.4 \mathrm{kcal} \mathrm{mol}^{-1}$ (Cys). ${ }^{46-49}$ Therefore, concerning the Cys and Met complexation, we can say that the reactions with $\left[\mathrm{Pt}(\mathrm{AHTC}) \mathrm{Cl}\left(\mathrm{H}_{2} \mathrm{O}\right)\right]^{+}$species are faster than with cisplatin, with the Cys complex being the kinetic product. In the reaction of $\mathrm{G}$ with cisplatin monoaqua species described 
in reference 27, the contributions from entropy and solvent were close to $9 \%$ and $3 \%$, respectively, in accordance with the results found here. The calculated barrier for $\mathrm{G}$ binding to cisplatin was $20.9 \mathrm{kcal} \mathrm{mol}^{-1}{ }^{27}$ which are only $0.5 \mathrm{kcal} \mathrm{mol}^{-1}$ lower than the calculated value reported in the present work for the hybrid complex with AHTC vector ligand. If we consider our highest level of theory (B3LYP/6-311+G(2d,p)/LanL2DZ//B3LYP/6-31G(d)/ LanL2DZ) the predicted value is $20.7 \mathrm{kcal} \mathrm{mol}^{-1}$, being $0.2 \mathrm{kcal} \mathrm{mol}^{-1}$ lower than those found for cisplatin. The experimental value for $\mathrm{G}$ binding spread over a range from 17.8 to $18.9 \mathrm{kcal} \mathrm{mol}^{-1}$, involving measurements with much more complex DNA matrix ${ }^{50,51}$ and then, are not directly compared to the processes studied here. The G and A interactions with diaquated cisplatin was reported recently by Eriksson and co-workers ${ }^{44}$ using DFT calculations at the same level we applied in the present study. The calculated activation barriers in aqueous solution were 19.5 for $\mathrm{G}$ and $24.0 \mathrm{kcal} \mathrm{mol}^{-1}$ for $\mathrm{A}$, with the former found in good agreement with the experimental data used $\left(18.3 \mathrm{kcal} \mathrm{mol}^{-1}\right)$. These values are also close to ours ( 21.4 and 23.1 for $G$ and A, respectively), despite the great difference in the systems and processes analyzed.

The transition state theory (TST) developed by Eyring has been most used in chemical kinetics studies. ${ }^{52}$ This approach can be summarized by equation 6 , where $\mathrm{k}_{\mathrm{B}}$ is the Boltzmann constant, $\mathrm{T}$ the absolute temperature $(298.15 \mathrm{~K}$ in the present work), $\mathrm{h}$ the Planck constant and $\Delta \mathrm{G}_{\mathrm{a}}$ is the activation free energy for the reaction, calculated as in equations 2 and 3.

$\mathrm{k}_{2}=\frac{\mathrm{k}_{\mathrm{B}} \mathrm{T}}{\mathrm{hc}^{\mathrm{o}}} \mathrm{e}^{-\Delta \mathrm{G}_{\mathrm{a}} / \mathrm{RT}}$

$\mathrm{k}_{2}$ is the second order rate constant, which is a function of temperature, calculated at standard concentration of $\mathrm{c}^{0}=1 \mathrm{~mol} \mathrm{~L}^{-1}$. It is interesting to point out that the rate constants are much more sensitive than the activation free energy, moreover a small fluctuation in $\Delta \mathrm{G}_{\mathrm{a}}$ value, around $1 \mathrm{kcal} \mathrm{mol}^{-1}$ as found in reference 28 , shall generate a wide spread range for $k_{2}$. The second order rate constants for the processes studied here were calculated in aqueous solution with values given in the last column of Table 4 . The $\Delta \mathrm{G}_{\mathrm{a}, \mathrm{aq}}$ values (see equation 3 ) were used for calculation of rate constants. For reaction with $\mathrm{G}, \mathrm{k}_{2}$ values were 0.1-0.4 $\times 10^{-2} \mathrm{~mol}^{-1} \mathrm{~L} \mathrm{~s}^{-1}$, which are close to those calculated for the parent complex cisplatin in reference 27, $0.1-0.3 \times 10^{-2} \mathrm{~mol}^{-1} \mathrm{~L} \mathrm{~s}^{-1}$. Experimental data for cisplatin shows values one order of magnitude higher, spreading over a broad range of $0.8-5.4 \times 10^{-1} \mathrm{~mol}^{-1} \mathrm{~L} \mathrm{~s}^{-1} .{ }^{50,51}$ For the amino acids the processes are faster, with rate constants found equal to 9.8-74.1 $\times 10^{-2} \mathrm{~mol}^{-1} \mathrm{~L} \mathrm{~s}^{-1}$ for Cys and
3.6-17.6 $\times 10^{-2} \mathrm{~mol}^{-1} \mathrm{~L} \mathrm{~s}^{-1}$ for Met. These results differ from those calculated for cisplatin at the same level reported in reference $28,0.1 \times 10^{-2} \mathrm{~mol}^{-1} \mathrm{~L} \mathrm{~s}^{-1}$ (Cys) and $0.79 \times 10^{-2} \mathrm{~mol}^{-1} \mathrm{~L} \mathrm{~s}^{-1}$, but are closer to the experimental data for the parent compound: $2.2-3.86 \times 10^{-2}$ and 3.6-3.96 $\times 10^{-2} \mathrm{~mol}^{-1} \mathrm{~L} \mathrm{~s}^{-1}$ for Cys and Met interactions, ${ }^{46-49}$ respectively. Finally, the kinetic study described in the present work shows that the AHTC-Pt follows closer the standard mechanism of action of cisplatin, with the same rate profile as represented in Scheme 3, therefore this new compounds may be assigned as a promising lead molecule in the synthesis of novel antitumor drugs. We are now engaged in going beyond the simple models for DNA and proteins, including in the calculations the backbone of the biomolecules. This is an essential step in order to definitively understand the hypothesis of the antitumor action mode of tetracycline and its derivatives.

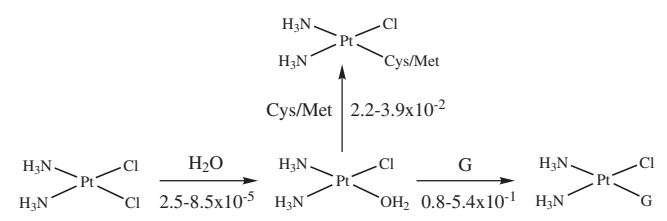

(a)

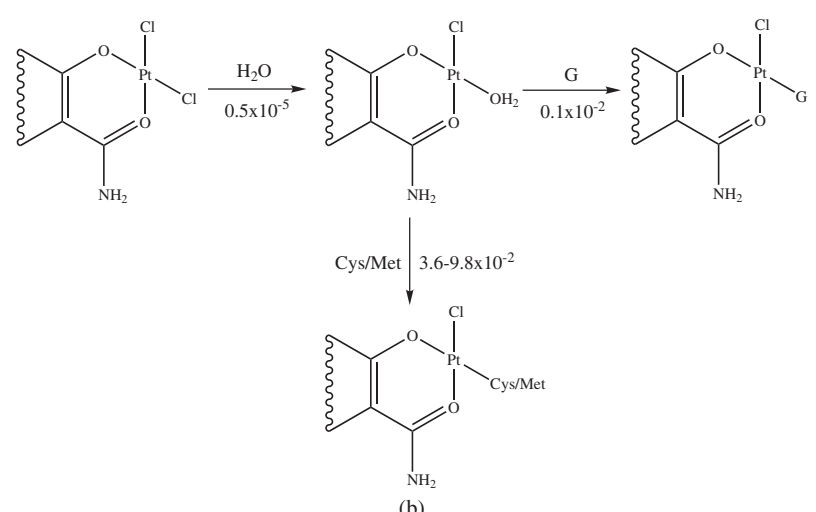

Scheme 3. Standard action mode for cisplatin derivatives. The first step is the hydrolysis (interaction with $\mathrm{H}_{2} \mathrm{O}$ ), following by binding to DNA bases, represented here by guanine $(\mathrm{G})$. The interaction with proteins, as indicated by the binding processes with Cys or Met, is also shown as a side process. (a) Processes for cisplatin parent compound. The values correspond to the experimental rate constants (in $\mathrm{mol}^{-1} \mathrm{~L} \mathrm{~s}^{-1}$ ) collected from literature. (b) Processes for AHTC-Pt derivative with $\mathrm{k}_{2}$ (in $\mathrm{mol}^{-1} \mathrm{~L} \mathrm{~s}^{-1}$ ) values obtained from DFT calculations carried out in our previous paper (hydrolysis reaction only) and in the present work.

\section{Conclusions}

The interaction of AHTC-Pt complex with relevant biological nucleophiles (guanine, adenine, cysteine and methionine) were investigated by means of theoretical methods based on DFT approach. These reactive processes follow the standard action mode of cisplatin analogues, 
comprising the activation hydrolysis step and binding to DNA bases ( $\mathrm{G}$ and $\mathrm{A}$ ). The interaction with sulfurcontaining amino acids also plays a primary role in determining the bioavailability of the drug, therefore the understanding of the reaction mechanism at a molecular level may assist in the design of new molecules with potential biological response.

The hydrolysis processes, leading to $[\mathrm{Pt}(\mathrm{AHTC})$ $\left.\mathrm{Cl}\left(\mathrm{H}_{2} \mathrm{O}\right)\right]^{+}$was studied in our previous paper given secondorder rate constant $\left(\mathrm{k}_{2}\right)$ equal to $0.5 \times 10^{-5} \mathrm{~mol}^{-1} \mathrm{~L} \mathrm{~s}^{-1}$, which is close to the value observed for the parent molecule cisplatin $\left(2.5-8.5 \times 10^{-5} \mathrm{~mol}^{-1} \mathrm{~L} \mathrm{~s}^{-1}\right)$. The following processes involved the aquated species, yielding the products [Pt(AHTC) $\mathrm{Cl}(\mathrm{Nu})]^{+}$with $\mathrm{Nu}=\mathrm{G}, \mathrm{A}$, Cys and Met. The structures of these molecules were described in addition to the ${ }^{1} \mathrm{H}$ and ${ }^{13} \mathrm{C}$ NMR spectra. The ${ }^{1} \mathrm{H}$ NMR was more sensitive, showing some fingerprints for $\mathrm{A}$ and $\mathrm{G}$ adducts. For these species the substituent at position $\mathrm{C} 6$ of the purine bases was found to be in close contact with methyl groups at C4 of AHTC, splitting and shifting down field the signs assigned to the $-\mathrm{CH}_{3}$ groups relative to the corresponding values for the free ligand. Taking the average chemical shift for the three hydrogen atoms, we found $\delta$ at $2.8 \mathrm{ppm}$ for both $-\mathrm{CH}_{3}$ groups in the free AHTC ligand and their complexes with Cys and Met. Nonetheless, for A and G two peaks are predicted at 2.8 and $3.3 \mathrm{ppm}$ (A) and 3.2 and $3.8 \mathrm{ppm}(\mathrm{G})$.

The whole reaction pathway was tracked for each process analyzed, with the kinetic properties calculated within the supermolecule approach. In this methodology the reagents and products are treated as molecular complexes, where the structures are determined following the intrinsic reaction coordinate starting form the transition states (TS). The TS species play a key role on the activation barrier and can not be assessed experimentally; therefore the theoretical description given in the present study can be valuable for experimentalists in planning molecules and processes with controlled reactivity. For reactions analyzed here the rate constants were $\left(10^{2} \mathrm{k}_{2}\right.$ in $\left.\mathrm{mol}^{-1} \mathrm{~L} \mathrm{~s}^{-1}\right): 0.1(\mathrm{G}), 0.01(\mathrm{~A})$, 3.6 (Met) and 9.8 (Cys). These values are $10^{3}$ times faster than the hydrolysis process, which is in perfect accordance with the expected behavior for standard cisplatin analogues. Comparing to experimental data for cisplatin, $8-54 \times 10^{-2}$ (G) and 2.2-3.9 $\times 10^{-2} \mathrm{~mol}^{-1} \mathrm{~L} \mathrm{~s}^{-1}$ (Cys and Met) we noted that the reaction of AHTC-Pt derivative with $\mathrm{G}$ is almost two orders of magnitude slower and the interaction with Cys or Met slightly faster. Indeed the values predicted for AHTC-Pt compare well with cisplatin, considering the differences in the coordination shells and, consequently, in the processes investigated. It is worth mentioning that rate constant is a very sensitive quantity and then, the values may change significantly with small fluctuation in the activation free energy.

\section{Acknowledgments}

The authors would like to thank the Brazilian Agencies CNPq (Conselho Nacional de Desenvolvimento Científico e Tecnológico) and FAPEMIG (Fundação de Amparo à Pesquisa do Estado de Minas Gerais) for financial support. This work was partially supported by the projects PRONEX-FAPEMIG/EDT-526/07.

\section{Supplementary Information}

Supplementary data are available free of charge at http:// jbcs.sbq.org.br, as PDF file.

\section{References}

1. Chopra, I.; Roberts, M.; Microbiol. Mol. Biol. Rev. 2001, 65, 232.

2. Hidalgo, M.; Eckhardt, S. G.; J. Nat. Cancer Inst. 2001, 93, 178.

3. Kisker, C.; Hinrichs, W.; Tovar, K.; Hillen, W.; Saenger, W.; J. Mol. Biol. 1995, 247, 260.

4. Leypold, C. F.; Marian, D.-T.; Roman, C.; Schneider, S.; Schubert, P.; Scholz, O.; Hillen, W.; Clark, T.; Lanig, H.; Photochem. Photobiol. Sci. 2004, 3, 109.

5. Kedracka-Krok, S.; Gorecki, A.; Bonarek, P.; Wasylewski, Z.; Biochemistry 2005, 44, 1037.

6. Lanig, H.; Othersen, O. G.; Seidel, U.; Beierlein, F. R.; Exner, T. E.; Clark, T.; J. Med. Chem. 2006, 49, 3444.

7. Wessels, J. M.; Ford, W. E.; Szymczak, W.; Schneider, S.; J. Phys. Chem. B 1998, 1029323.

8. De Paula, F. S.; Carvalho, S.; Duarte, H. A.; Paniago, E. B.; Mangrich, A. S.; Pereira-Maia, E. C.; J. Inorg. Biochem. 1999, $76,221$.

9. Aly, A. A. M.; Strasser, A.; Vogler, A.; Inorg. Chem. Comm. 2002, 5, 411.

10. Schneider, S.; Schmitt, M. O.; Brehm, G.; Reither, M.; Matousek, P.; Towrie, M.; Photochem. Photobiol. Sci. 2003, $2,1107$.

11. Chartone-Souza, E.; Loyola, T. L.; Bucciarelli-Rodriguez, M.; Menezes, M. A. B. C.; Rey, N. A.; Pereira-Maia, E. C.; J. Inorg. Biochem. 2005, 99, 1001.

12. Guerra, W.; Silva, I. R.; Azevedo, E. A.; Monteiro, A. R. S.; Bucciarelli-Rodriguez, M.; Chartone-Souza, E.; Silveira, J. N.; Fontes, A. P. S.; Pereira-Maia, E. C.; J. Braz. Chem. Soc. 2006, 17, 1627.

13. van Zutphen, S.; Reedijk, J.; Coord. Chem. Rev. 2005, 249 , 2845. 
14. Ackley, M. C.; Barry, C. G.; Mounce, A. M.; Farmer, M. C.; Springer, B.-E.; Day, C. S.; Wright, M. W.; Berners-Price, S. J.; Hess, S. M.; Bierbach, U.; J. Biol. Inorg. Chem. 2004, 9, 453.

15. Guddneppanavar, R.; Wright, M. W.; Tomsey, A. K.; Bierbach, U.; J. Inorg. Biochem. 2006, 100, 972.

16. De Almeida, W. B.; Costa, L. R. A.; Dos Santos, H. F.; Zerner, M. C.; J. Chem. Soc., Perkin Trans. 2 1997, 1335.

17. Dos Santos, H. F.; De Almeida, W. B.; Zerner, M. C.; J. Pharm. Sci. 1998, 87, 190.

18. De Almeida, W. B.; Dos Santos, H. F.; Rocha, W. R.; Zerner, M. C.; J. Chem. Soc., Dalton Trans. 1998, 15, 2531.

19. De Almeida, W. B.; Dos Santos, H. F.; Zerner, M. C.; J. Pharm. Sci. 1998, 87, 1101.

20. Dos Santos, H. F.; Zerner, M. C.; De Almeida, W. B.; J. Chem. Soc., Perkins Trans. 2 1998, 2519.

21. Dos Santos, H. F.; Xavier, E. S.; Zerner, M. C.; De Almeida, W. B.; THEOCHEM 2000, 527, 193.

22. Dos Santos, H. F.; Nascimento, Jr., C. S.; Belletato, P.; De Almeida, W. B.; THEOCHEM 2003, 626, 305.

23. Dos Santos, H. F.; Marcial, B. L.; De Miranda, C. F.; Costa, L. A. S.; De Almeida, W. B.; J. Inorg. Biochem. 2006, 100, 1594.

24. Costa, L. A. S.; Rocha, W. R.; De Almeida, W. B.; Dos Santos, H. F.; J. Chem. Phys. 2003, 118, 10584.

25. Costa, L. A. S.; Rocha, W. R.; De Almeida, W. B.; Dos Santos, H. F.; Chem. Phys. Lett. 2004, 387, 182.

26. Costa, L. A. S.; Rocha, W. R.; De Almeida, W. B.; Dos Santos, H. F.; J. Inorg. Biochem. 2005, 99, 575.

27. Costa, L. A. S.; Hambley, T. W.; Rocha, W. R.; De Almeida, W. B.; Dos Santos, H. F.; Int. J. Quantum Chem. 2006, 106, 2129 and references therein.

28. Da Silva, V. J.; Costa, L. A. S.; Dos Santos, H. F.; Int. J. Quantum Chem. 2008, 108, 401 and references therein.

29. Coley, R. F.; Martin, D. S.; Inorg. Chim. Acta 1972, 7, 573.

30. Miller, S. E.; Gerard, K. J.; House, D. A.; Inorg. Chim. Acta 1991, 190, 135.

31. Jestin, J.-L.; Chottard, J.-C.; Frey, U.; Laurenczy, G.; Merbach, A. E.; Inorg. Chem. 1994, 33, 4277.

32. Gonzalez, C.; Schlegel, H. B.; J. Chem. Phys. 1989, 90, 2154.

33. Becke, A. D.; Phys. Rev. A 1988, 38, 3098.

34. Lee, C.; Yang, W.; Parr, R. G.; Phys. Rev. B 1988, 37, 785.

35. Hay, P. J.; Wadt, W. R.; J. Chem. Phys. 1985, 82, 270.

36. Cancès, M. T.; Mennucci, B.; Tomasi, J.; J. Chem. Phys. 1997, 107, 3032.

37. Frisch, M. J.; Trucks, G. W.; Schlegel, H. B.; Scuseria, G. E.; Robb, M. A.; Cheeseman, J. R.; Montgomery, Jr., J. A.; Vreven, T.; Kudin, K. N.; Burant, J. C.; Millam, J. M.; Iyengar, S. S.;
Tomasi, J.; Barone, V.; Mennucci, B.; Cossi, M.; Scalmani, G.; Rega, N.; Petersson, G. A.; Nakatsuji, H.; Hada, M.; Ehara, M.; Toyota, K.; Fukuda, R.; Hasegawa, J.; Ishida, M.; Nakajima, T.; Honda, Y.; Kitao, O.; Nakai, H.; Klene, M.; Li, X.; Knox, J. E.; Hratchian, H. P.; Cross, J. B.; Bakken, V.; Adamo, C.; Jaramillo, J.; Gomperts, R.; Stratmann, R. E.; Yazyev, O.; Austin, A. J.; Cammi, R.; Pomelli, C.; Ochterski, J. W.; Ayala, P. Y.; Morokuma, K.; Voth, G. A.; Salvador, P.; Dannenberg, J. J.; Zakrzewski, V. G.; Dapprich, S.; Daniels, A. D.; Strain, M. C.; Farkas, O.; Malick, D. K.; Rabuck, A. D.; Raghavachari, K.; Foresman, J. B.; Ortiz, J. V.; Cui, Q.; Baboul, A. G.; Clifford, S.; Cioslowski, J.; Stefanov, B. B.; Liu, G.; Liashenko, A.; Piskorz, P.; Komaromi, I.; Martin, R. L.; Fox, D. J.; Keith, T.; Al-Laham, M. A.; Peng, C. Y.; Nanayakkara, A.; Challacombe, M.; Gill, P. M. W.; Johnson, B.; Chen, W.; Wong, M. W.; Gonzalez, C.; Pople, J. A.; Gaussian 03, Revision D.01, Gaussian, Inc.: Wallingford CT, 2004.

38. Wolinski, K.; Hilton, J. F.; Pulay, P.; J. Am. Chem. Soc. 1990, $112,8251$.

39. Lee, J. Y.; Everett Jr., G. W.; J. Am. Chem. Soc. 1981, 103, 5221.

40. Alderden, R. A.; Hall, M. D.; Hambley, T. W.; J. Chem. Educ. 2006, 83, 728 .

41. Zimmermann, T.; Zeizinger, M.; Burda, J. V.; J. Inorg. Biochem. 2005, 99, 2184 and references therein.

42. Pavelka, M.; Burda, J. V.; J. Mol. Model. 2007, 13, 367 and references therein.

43. Addison, A. W.; Rao, T. N.; Reedijk, J.; van Rijn, J.; Verschoor, G. C.; J. Chem. Soc. Dalton Trans. 1984, 7, 1349.

44. Raber, J.; Zhu, C.; Eriksson, L. A.; J. Phys. Chem. B 2005, 109, 11006.

45. Aullón, G.; Bellamy, D.; Guy Orpen, A.; Brammer, L.; Bruton, E. A.; Chem. Commun. 1998, 653.

46. Dedon, P. C.; Borch, R. F.; Biochem. Pharmacol. 1987, 36, 1955.

47. Bednarski, P. J.; J. Biol. Inorg. Chem. 1995, 80, 1.

48. Bose, R. N.; Ghosb, S. K.; Moghaddas, S.; J. Inorg. Biochem. 1997, 65, 199.

49. Zou, J.; dong Yang, X.; An, F.; Wang, K.; J. Inorg. Biochem. 1998, 70, 227.

50. Kozelka, J.; Legendre, F.; Reeder, F.; Chottard, J.-C.; Coord. Chem. Rev. 1999, 61, 190.

51. Eastman, A.; Barry, M. A.; Biochemistry 1987, 26, 3303.

52. Connors, K. A.; Chemical Kinetics-The Study of Reaction Rate in Solution, Wiley: New York, 1990, p. 200.

Received: February 7, 2008 Web Release Date: September 3, 2008 


\section{Reactivity of 5a,6-Anhydrotetracycline Platinum(II) Complex with Biological Nucleophiles: A Theoretical Study}

\section{Bruna L. Marcial, ${ }^{a}$ Luiz Antônio S. Costa, ${ }^{b}$ Wagner B. De Almeida ${ }^{c}$ and Hélio F. Dos Santos $*, a$}

${ }^{a}$ Núcleo de Estudos em Química Computacional, Departamento de Química, Universidade Federal de Juiz de Fora, 36036-330 Juiz de Fora-MG, Brazil

${ }^{b}$ Escola Preparatória de Cadetes do Ar, Departamento de Ensino da Aeronáutica, Comando da Aeronáutica, Rua Santos Dumont, 149, 36205-970 Barbacena-MG, Brazil

'Laboratório de Química Computacional e Modelagem Molecular, Departamento de Química, Universidade Federal de Minas Gerais, 31270-901 Belo Horizonte-MG, Brazil

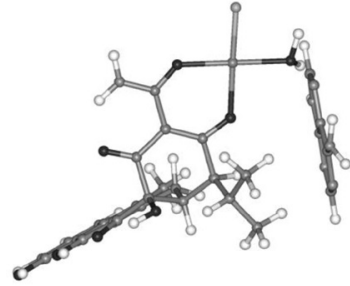

I-1 (-2610.6411797)

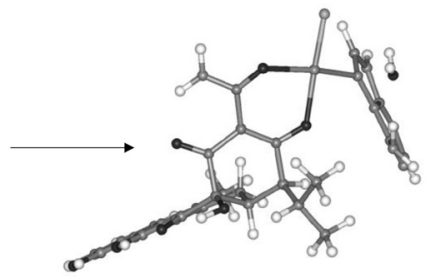

I-2 (-2610.6516153)

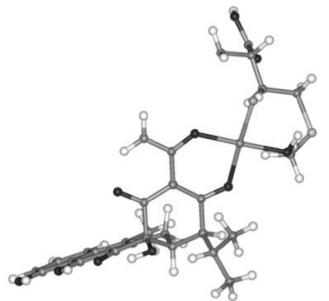

I-1 (-2943.8551307)

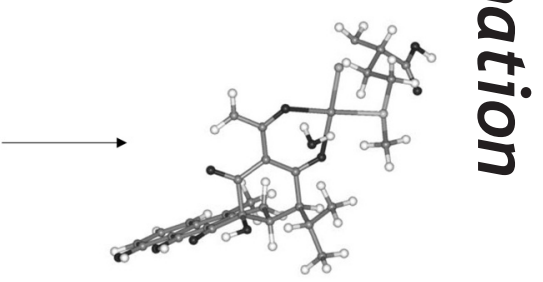

I-2 (-2943.8665778)

Reaction with Cys:

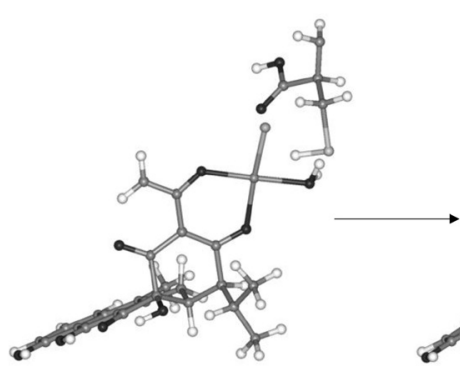

I-1 (-2865.227292)

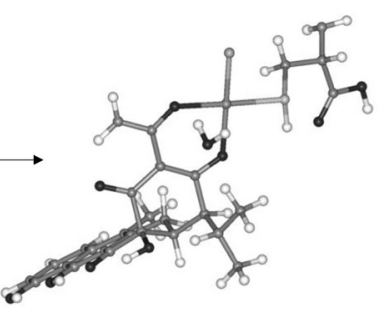

I-2 (2865.2344339)

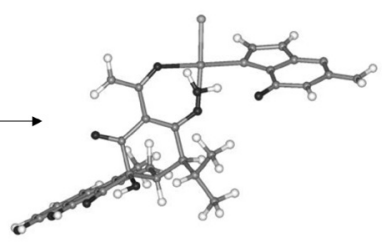

I-2 (-2685.8927435)

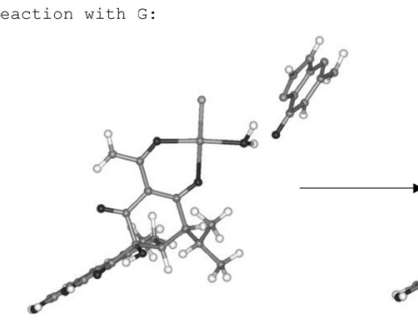

I-1 (-2685.8865604)

Figure S1. B3LYP/6-31G(d)/LanL2DZ optimized geometries for the intermediates (I-1 and I-2) involved in the reaction path for formation of [Pt(AHTC) $\mathrm{Cl}(\mathrm{Nu})]^{+}$complexes, where Nu stands by $\mathrm{A}, \mathrm{G}$, Met and Cys, respectively. Values of the total energy are given in parenthesis (in a.u.). 